\title{
Isolation and characterization of behavioural mutants and genes of Agrobacterium tumefaciens
}

\author{
C. H. Shaw, * G. J. Loake, A. P. Brown, C. S. Garrett, W. Deakin, G. Alton, M. Hall, \\ S. A. Jones, M. O'Leary and L. Primavesi \\ Department of Biological Sciences, University of Durham, South Road, Durham DH1 3LE, UK
}

(Received 30 November 1990; revised 12 February 1991; accepted 16 April 1991)

\begin{abstract}
Agrobacterium tumefaciens exhibits an unusual flagellation pattern in the electron microscope. The typical pattern is of two flagella in a polar or sub-polar tuft at one pole only, plus one or two lateral flagella on each side. Twenty independent behavioural mutants were isolated, after $\operatorname{Tn} 5$ mutagenesis, and divided into several classes. Fourteen non-motile mutants were differentiable into non-flagellate and flagellate subclasses, one non-chemotactic mutant appeared to have a defect in the intracellular signalling pathway, and one other mutant displayed an unusual pattern of polar cell pairing. Four mutants with impaired swarming ability were also isolated. Root colonization ability was impaired in the non-motile mutant for which this property was tested. From all but three of the mutants, the Tn5 insertion sites, including flanking sequences, have been cloned and used as probes to isolate a set of seven cosmids from a wild-type $A$. tumefaciens library. No hybridization to Escherichia coli or Pseudomonas DNA was detected for the $A$. tumefaciens mutant flanking sequences, but varying degrees of similarity to Rhizobium meliloti behavioural genes were detected. By complementation of $A$. tumefaciens behavioural mutants and hybridization of mutant flanking sequences, one cosmid insert was shown to contain at least nine behavioural loci, and another, linked to it on the chromosome, at least three. This suggests that, as in other organisms, behavioural genes are clustered in the $A$. tumefaciens genome.
\end{abstract}

\section{Introduction}

Bacteria exhibit behaviour, in their responses to external stimuli. The best-characterized of these is chemotaxis, the response to a temporal gradient of attractant or repellent (Bourret et al., 1989; Macnab, 1987b; Stewart \& Dahlquist 1987; Stock et al., 1990; Taylor \& Lengeler 1990). For chemotaxis, the organism must be motile. In the enteric bacteria, it is estimated that approximately 60 genes contribute to this phenomenon, although the bulk are concerned with flagellar structure (Macnab, 1987a). Evidence is accumulating to suggest that chemotaxis play a major role in the ecology of many bacteria. For instance, non-motile Rhizobium mutants are less competitive nodulators than their wild-type parents (Ames \& Bergman, 1981), and non-chemotactic Agrobacterium mutants are impaired in virulence under certain conditions (Hawes \& Smith, 1989; Hawes et al., 1988).

Crown gall occurs on plants after infection of wounded tissue by Agrobacterium tumefaciens (Howard \& Citovsky, 1990; Zambryski et al., 1989). Laboratory experiments have indicated that chemotaxis towards plant exudates is an initial step in this interaction (Ashby et al., 1987, 1988; Loake et al., 1988; Shaw et al., 1988a). It is therefore of importance to investigate motility and chemotaxis in this organism. In this paper, we describe the creation of $\mathrm{Tn} 5$-induced mutants defective in chemotaxis and motility, and the isolation and partial characterization of their corresponding genes.

\section{Methods}

Bacterial strains and growth media. The parent strain used to create the behavioural mutants was the highly motile (Loake et al., 1988) strain A. tumefaciens C58C1 Rif (van Larebeke et al., 1974) periodically enriched for motile bacteria by passage through swarm plates containing $0 \cdot 2 \%$ agar (Loake et al., 1988). The construction of $A$. tumefaciens $\mathrm{C} 58 \mathrm{Cl}$ (pGV2201) carrying a virulent nopaline Ti-plasmid, with a streptomycin resistance gene inserted into the right end of the TDNA, was described previously (Leemans et al., 1981). Escherichia coli 1830(pJB4JI) and pLAFR3 (Staskawicz et al., 1987) were obtained from $\operatorname{Dr}$ M. Daniels (Sainsbury Laboratory, Norwich, UK). $A$. tumefaciens GM19023 (Rosenberg \& Huguet, 1984) cured of its Ti- and cryptic plasmids was obtained from Dr J. Denarie (Toulouse, France). Rhizobium meliloti and the cosmids pRZ2 and pRZ4 (Ziegler et al., 1986), carrying Rhizobium behavioural genes, were obtained from $\mathrm{Dr}$ K. Bergman (Boston, MA, USA). R. leguminosarum biovars viciae and phaseoli were obtained from Professor A. Johnston (Norwich). 
Pseudomonas talassii and $P$. reactans were obtained from Dr A. M. Ashby (Cambridge, UK). Bacterial cultures were grown in either Rhizobium Initiation Medium (RIM) (Aguilar et al., 1988), L-broth or Minimal A (MinA) supplemented with glucose (Miller, 1972; Shaw et al., 1988a) and after centrifugation, washed and resuspended in chemotaxis medium (CM) (Adler, 1973; Ashby et al., 1987, 1988). Antibiotic concentrations and all conjugations were as previously described (Leemans et al., 1981; Shaw et al., 1988a).

Chemotaxis assays. The capillary assay (Adler, 1973) was employed, using a $60 \mathrm{~min}$ incubation time. Bacteria attracted into capillaries were plated out onto selective media (Ashby et al., 1987, 1988). Alternatively, blindwell assays (Shaw et al., 1988a) in triplicate were performed, the bacterial number attracted into the attractant chamber being measured in a Coulter counter.

Microscopy. After washing and resuspension in chemotaxis medium, motility of each strain was checked using a Nikon Optiphot microscope utilizing phase-contrast optics, and a Hitachi HV-720K CCTV camera. Behaviour and speed measurements were made during slow-motion playback of recorded motility, using a Ferguson 3V23 video recorder, a Panasonic WJ-810 time-date generator and a Hitachi VM-920K video monitor.

Electron microscopy. Samples $(20 \mu \mathrm{l})$ of bacteria were allowed to airdry onto Formvar-coated grids, then placed upside down onto $50 \mu \mathrm{l}$ drops of saturated uranyl acetate for $30 \mathrm{~s}$, washed by placing on several successive drops of distilled water, and air dried. Grids were observed in a Philips EM400, and photographed.

Isolation of chromosomal DNA. DNA was isolated using a scaled-up version of the mini-prep method for Agrobacterium chromosomal DNA (Dhaese et al., 1979). The DNA was subsequently purified by centrifugation in a caesium chloride gradient, dialysed and stored at $-20^{\circ} \mathrm{C}$.

DNA manipulation. Isolation of plasmid DNA, restriction enzyme digestions, vector phosphorylations, ligations, transformation of $E$. $c o l i$, and screening for recombinants were done by established protocols (Maniatis et al., 1982). To isolate each Tn5 insertion site, $28 \mu \mathrm{g}$ of EcoRI-cleaved chromosomal DNA from each of the behavioural mutants was ligated to $4 \mu \mathrm{g}$ of similarly-cut pUC18 or 19 and transformed into $E$. coli $\mathrm{DH} 5 \alpha$, with selection for ampicillin and kanamycin resistance. The wild-type $A$. tumefaciens $\mathrm{C} 58 \mathrm{Cl}$ library was constructed in pLAFR3. Total DNA from $A$. tumefaciens $\mathrm{C} 58 \mathrm{Cl}$ (cured of its Ti-plasmid) was partially digested with $B a m \mathrm{HI}$, and $20-25 \mathrm{~kb}$ fragments size-selected. These were ligated to Bam HI-cut pLAFR3 arms, packaged in vitro into phage heads, and introduced into $E$. coli HB101. Each of the cosmid clones was maintained separately, the library consisting of 1200 separate clones, which is in excess of the number of clones (820) required for $99 \%$ probability of finding any particular gene.

Southern blotting. Probes were labelled using the Amersham Multiprime kit. Restriction enzyme digests of bacterial DNA were separated by electrophoresis through $0.8 \%$ agarose gels, and blotted onto nitrocellulose or nylon. Hybridization was performed at $65^{\circ} \mathrm{C}$ in $6 \times$ SSC, and the blots washed at $65^{\circ} \mathrm{C}$ in $1 \times \mathrm{SSC}$.

Pulsed field gel electrophoresis. Bacteria were immobilized, lysed and their DNA restriction enzyme digested in $1 \%(w / v)$ low-melting-point agarose plugs (Flanagan et al., 1989). Plugs were placed in the wells of a $1.5 \%$ agarose gel, and DNA separated on a Bio-Rad CHEF DRII orthogonal-field electrophoresis apparatus, using a pulse time of $7 \mathrm{~s}$ at $150 \mathrm{~V}$ for $20 \mathrm{~h}$.

Virulence assays. Two-week-old sunflower seedlings were inoculated with $20 \mu$ l of an overnight culture of bacteria, grown for 2-3 weeks in a $1: 1$ peat/vermiculite mixture, and monitored for tumour growth.
Root colonization. The assay used was based on a published protocol (de Weger et al., 1987). Two-week-old potato plantlets, with $2-3 \mathrm{~cm}$ roots, were dipped into overnight bacterial cultures, and planted in soil in PVC tubes resting on a bed of vermiculite. After two weeks of further growth, during which time the plants were kept moist by watering the vermiculite bed, they were removed from the soil, and their roots cut into $1 \mathrm{~cm}$ sections. Ten sections from each root position were disrupted by agitation with fine glass beads, and the resultant slurry diluted and plated onto appropriate agar.

\section{Results}

\section{Motility and flagellation in A. tumefaciens}

Motility and flagellation in A. tumefaciens has not been extensively studied. Thus, it was crucial to establish the pattern of flagellation and motility of the wild-type parent, $A$. tumefaciens $\mathrm{C} 58 \mathrm{C} 1$, prior to mutagenesis. We have previously reported that this organism has a slightly unusual manner of motility, more reminiscent of Rhizobium than $E$. coli (Loake et al., 1988). Thus $A$. tumefaciens exhibits long runs with few tumbles, and appears to move by unidirectional clockwise flagellar rotation (Loake et al., 1988).

When observed by electron microscopy (see Methods) $A$. tumefaciens displays a slightly unusual fiagellation pattern (Fig. 1, Fig. 2, top left). The typical pattern is of a polar or slightly sub-polar tuft of two flagella, at only one pole, plus one or two lateral flagella on each side, amounting to a total of four to six flagella. It is not apparent whether the lateral flagella are symmetrically arranged or not. This does suggest a polarity of the cell, as far as flagellation is concerned. However, all the fiagella display the sinuous curves typical of a helical filament. Higher magnification of the flagellar filament reveals it to be approximately $10-12 \mathrm{~nm}$ in diameter.

\section{Mutagenesis and selection of behavioural mutants}

Preliminary chemical mutagenesis with ethyl methanesulphonate revealed that mutants impaired in swarming ability could be isolated from $A$. tumefaciens at a frequency of $6 \times 10^{-4}$ (data not shown). Experiments using a number of $\operatorname{Tn} 5$ suicide vectors demonstrated that pJB4JI had the highest transfer frequency from $E$. coli to A. tumefaciens. E. coli 1830 (pJB4JI) was conjugated with A. tumefaciens $\mathrm{C} 58 \mathrm{Cl} \mathrm{Rif}^{\mathrm{\gamma}}$, and plated onto L-agar containing rifampicin and kanamycin. Transconjugants, isolated at a frequency of $10^{-6}$, were screened for behavioural defects in L-swarm agar, containing rifampicin, kanamycin and $0.2 \%$ agar.

Twenty-two putative mutants, showing impaired swarming ability, were picked, subcultured twice, and retested. These mutants were isolated at a frequency of 


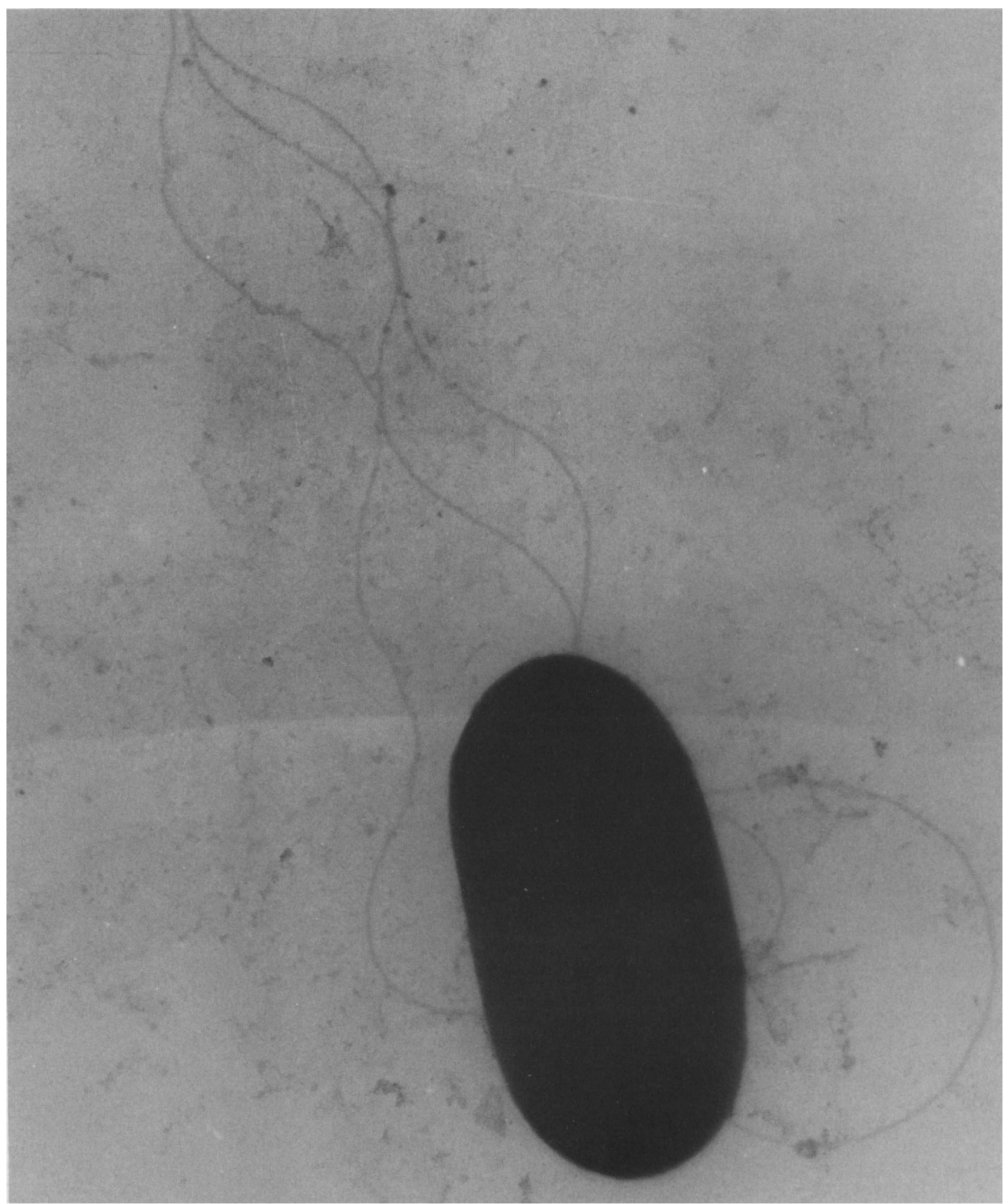

Fig. 1. Electron micrograph of $A$. tumefaciens $\mathrm{C} 58 \mathrm{Cl}$, stained with uranyl acetate. The cell body is approximately $1.2 \mu \mathrm{m}$ in length. 
Table 1. Classes of behavioural mutants

\begin{tabular}{|c|c|c|c|c|}
\hline Class & Subclass & Features & Mutant no. & Gene locus \\
\hline \multirow[t]{4}{*}{ Non-motile } & \multirow[t]{3}{*}{$\begin{array}{l}\text { Possess } \\
\text { flagella }\end{array}$} & $\begin{array}{l}\text { Normal } \\
\text { flagella* }\end{array}$ & $\begin{array}{r}5 \\
14\end{array}$ & $\begin{array}{l}m o t-5 \\
m o t-14\end{array}$ \\
\hline & & $\begin{array}{l}\text { Abnormal } \\
\text { flagella* }\end{array}$ & $\begin{array}{l}1 \\
4 \\
6 \\
9\end{array}$ & $\begin{array}{l}\text { mot-1 } \\
\text { mot }-4 \\
\text { mot }-6 \\
\text { mot }-9\end{array}$ \\
\hline & & $\begin{array}{l}\text { No polar } \\
\text { tuft }\end{array}$ & 12 & $m o t-12$ \\
\hline & $\begin{array}{l}\text { No visible } \\
\text { flagella }\end{array}$ & & $\begin{array}{r}3 \\
7 \\
8 \\
10 \\
11 \\
15 \\
19\end{array}$ & $\begin{array}{l}\text { fla-3 } \\
\text { fla-7 } \\
\text { fla-8 } \\
\text { fla-10 } \\
\text { fla-11 } \\
\text { fla-15 } \\
\text { fla-19 }\end{array}$ \\
\hline \multirow[t]{3}{*}{ Motile } & $\begin{array}{l}\text { Non- } \\
\text { chemotactic }\end{array}$ & $\begin{array}{l}\text { Tumbles } \\
\text { incessantly }\end{array}$ & 2 & che-2 \\
\hline & $\begin{array}{l}\text { Tandemly } \\
\text { paired cells }\end{array}$ & $\begin{array}{l}\text { Poor } \\
\text { motility }\end{array}$ & 17 & $t p c-17$ \\
\hline & $\begin{array}{l}\text { Small } \\
\text { swarms }\end{array}$ & & $\begin{array}{l}18 \\
20 \\
21 \\
22\end{array}$ & $\begin{array}{l}s s w-18 \\
s s w-20 \\
s s w-21 \\
s s w-22\end{array}$ \\
\hline
\end{tabular}

* As judged from electron micrographs.

$1.8 \times 10^{-2}$ per kanamycin-resistant transconjugant, which is within the expected range for a complex phenotype encoded by approximately $1 \%$ of the total genome. All of the mutants were sensitive to the antibiotics whose resistance is encoded by pJB4JI (except kanamycin) and could not retransfer their kanamycin resistance. This suggests that the mutations are due to insertion of $\operatorname{Tn} 5$ into the $A$. tumefaciens genome.

To confirm that impaired swarming ability was not due to a metabolic defect, growth in culture of the 22 putative mutants was assessed. All but two of the candidates (nos 13 and 16) grew at a similar rate to their wild-type parent, and these two were thus discarded. Of the remaining 20,15 appeared to be incapable of swarming, and five produced intermediate-sized swarms.

\section{Phenotypic analysis of behavioural mutants}

The putative behavioural mutants were subjected to further analysis by phase-contrast and electron microscopy (see Methods; Table 1). The former confirmed that 14 of the non-swarming mutants were non-motile. One of them, however, (no. 2), proved to be motile, but to tumble excessively, and was thus categorized as a presumptive non-chemotactic mutant (che-2). This mutant has a defect in the intracellular signalling pathway, showing reduced methylation of methyl-accepting chemotaxis proteins (MCPs) (A.P.B., G.J.L. \& C.H.S., unpublished).

Phase-contrast microscopy demonstrated a number of features of the intermediate-swarming mutants (Table 1). Mutant no. 17 has a strange phenotype, typified by the appearance of tandemly paired cells, apparently attached at the poles. The attachment appears strong, but extracellular, as both cells can clearly be distinguished in outline. The mutant grows normally, and does not produce filaments or arrays of more than two cells. Thus, it is unlikely to have a defect in cell division or separation. The slow swarming can be attributed to the fact that the tandem pairs swim more slowly and appear more clumsy in their movement than the wild-type. This mutant has been designated $t p c-17$ (tandem paired $c$ ells). The remaining intermediate swarmer mutants appear indistinguishable from the wild-type in their motility pattern, and chemotaxis in blindwell assays to a complex attractant mixture (data not shown). To denote the uncertainty about their lesion, these mutants have been designated ssw-18, 20-22 (small swarms).

Electron microscopy (Figs 2-4) has allowed the division of the 14 non-motile mutants into two subclasses (Table 1): those possessing flagella, which presumably are non-functional in some respect (designated mot-1, 4, $5,6,9,12$ and 14), and those without observable flagella (designated $f a-3,7,8,10,11,15$ and 19). The other 


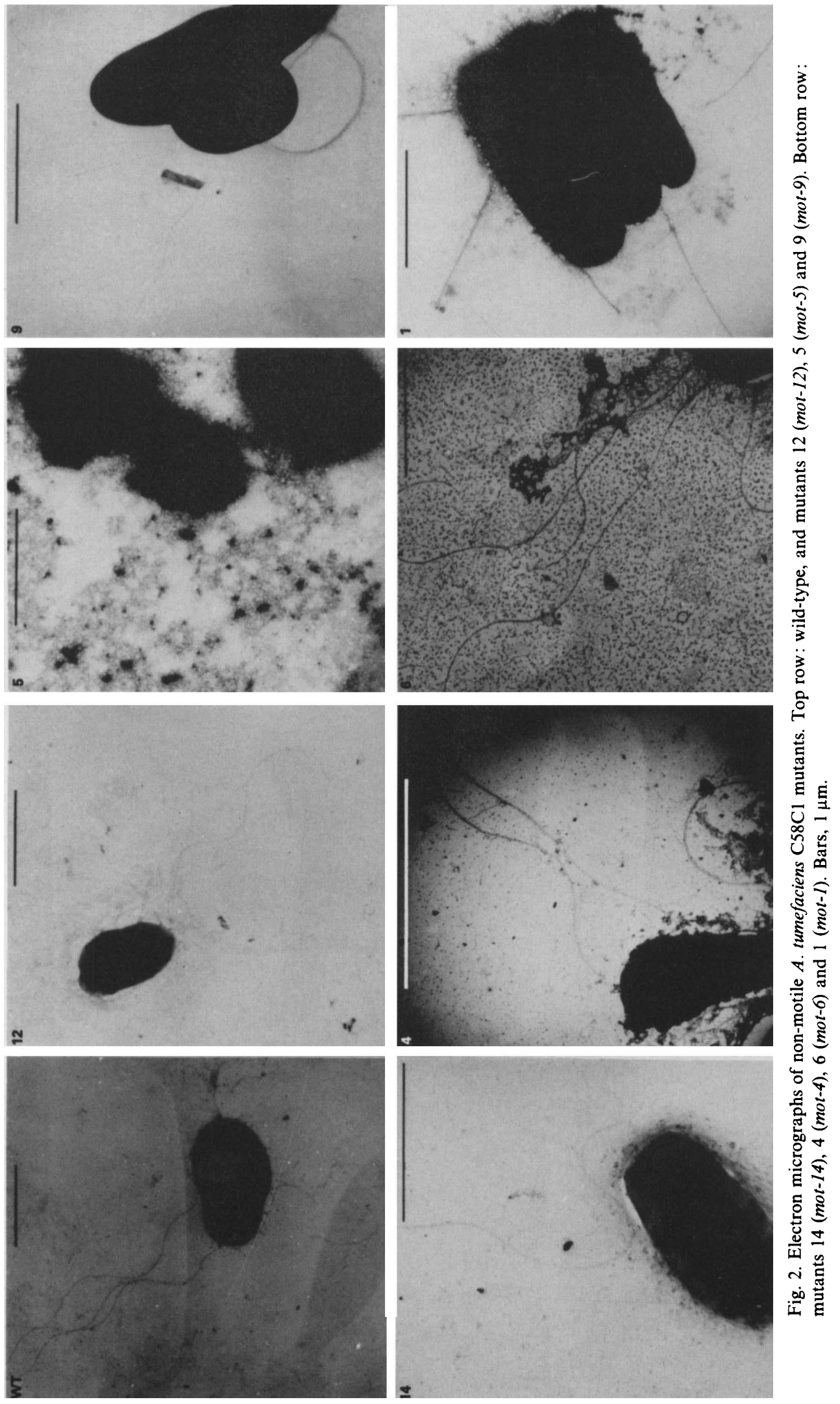



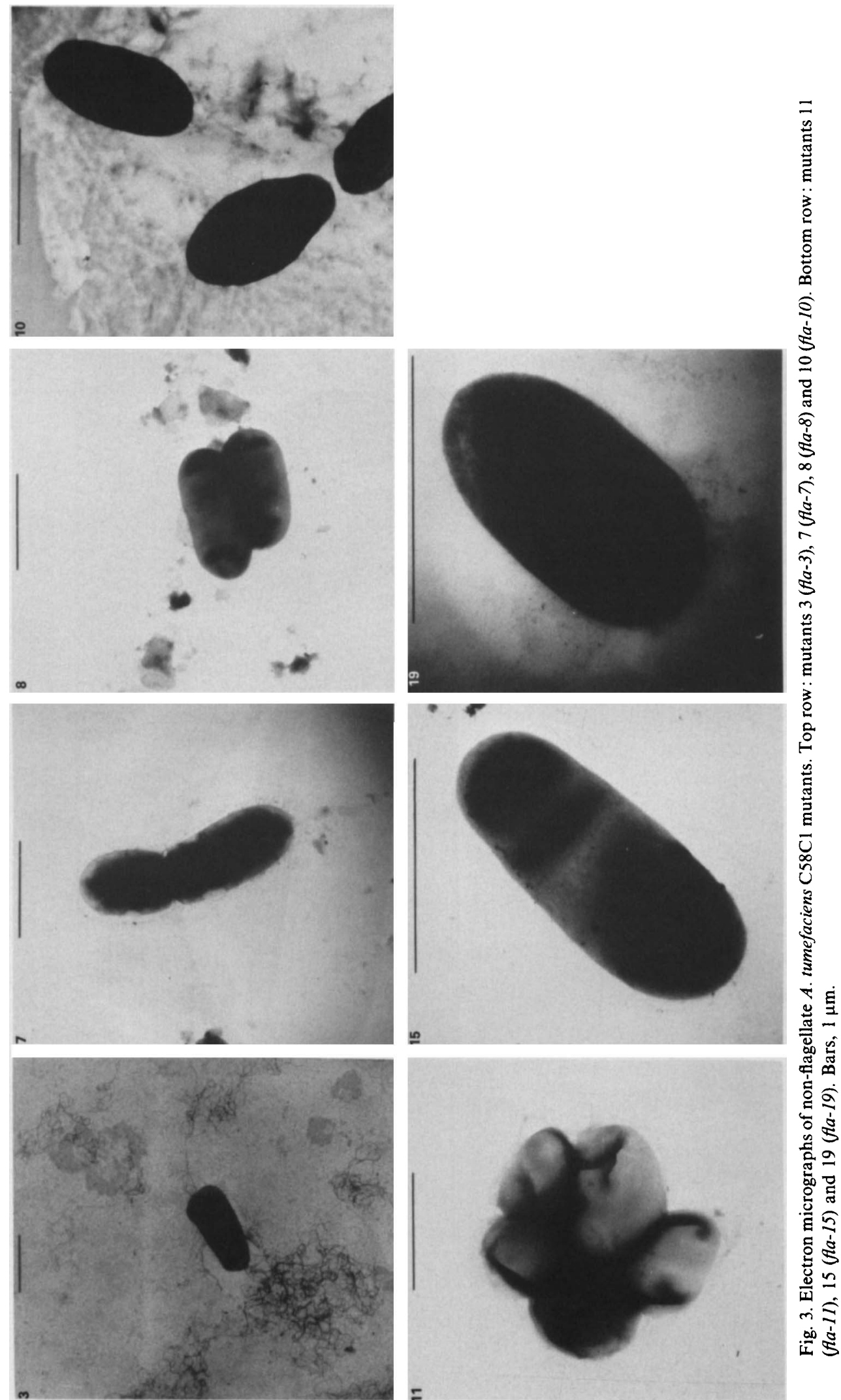

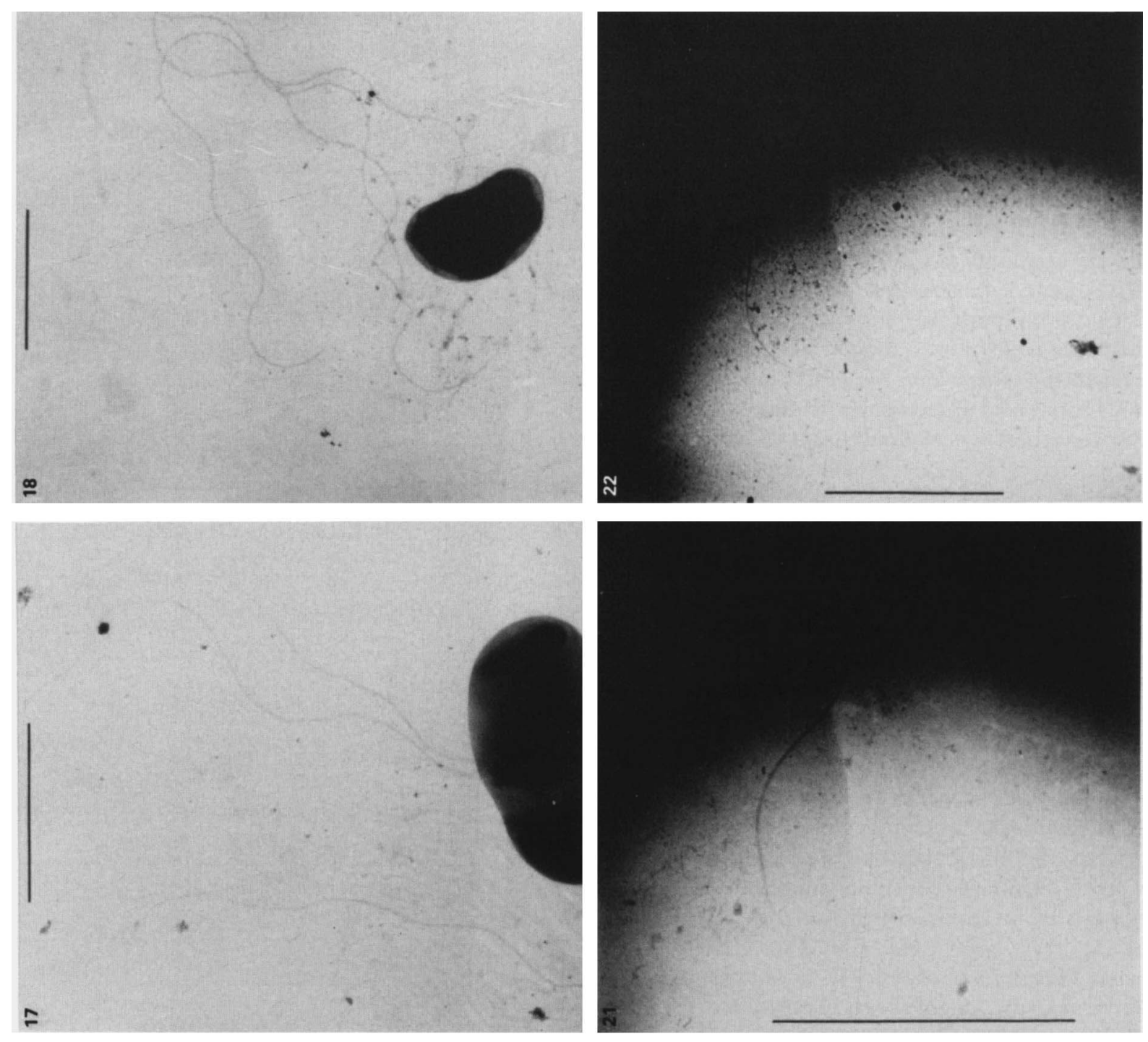

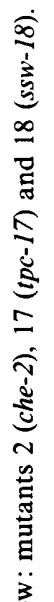
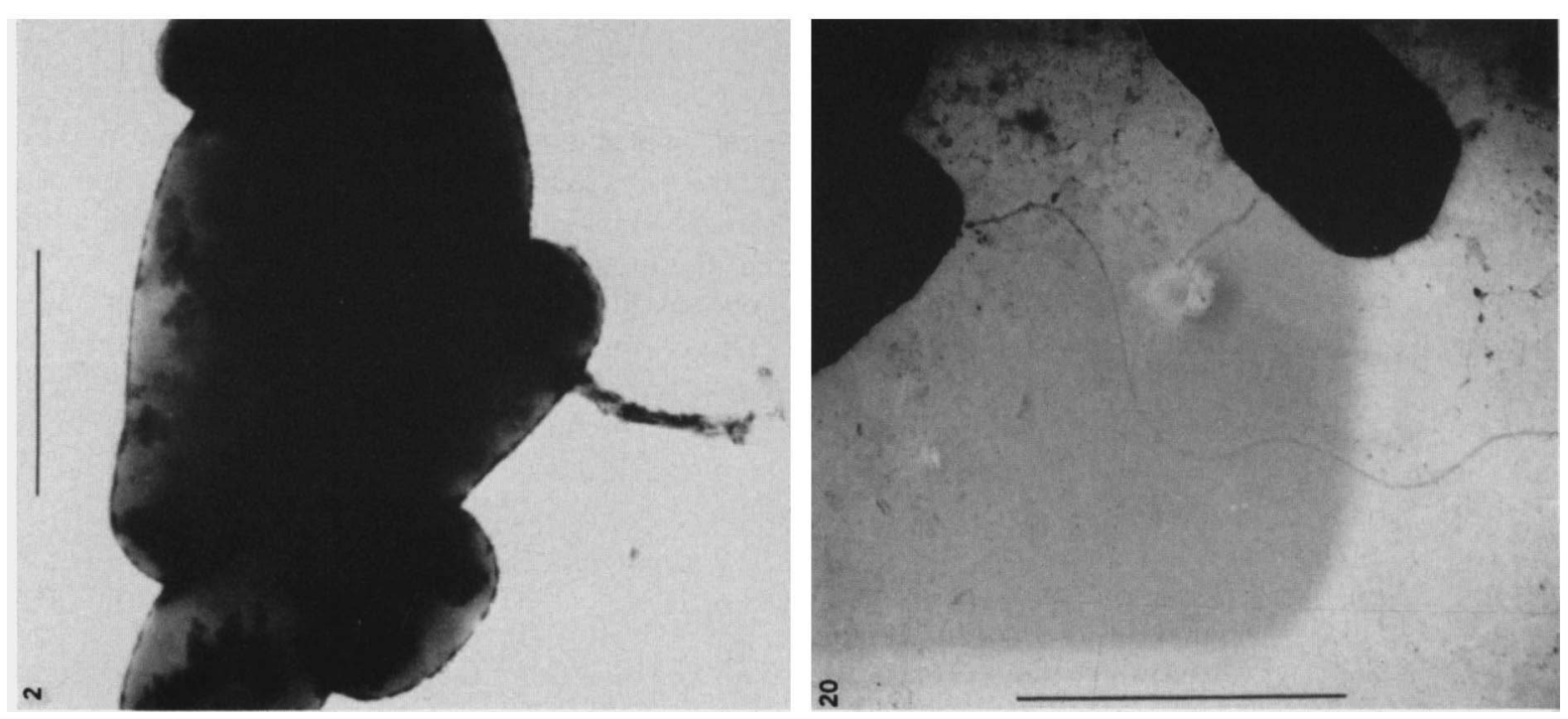

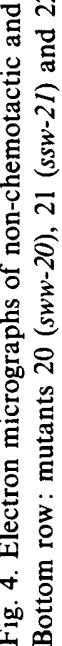


mutants, che-2 and ssw-, have flagellar structures indistinguishable from the wild-type (Table 1, Fig. 4).

\section{Biology of the behavioural mutants}

To assess the effect of the various mutations upon virulence of $A$.tumefaciens, the Ti-plasmid pGV2201 was conjugated into each of the mutants. When inoculated onto sunflower seedlings (see Methods), with $A$. tumefaciens $\mathrm{C} 58 \mathrm{Cl}$ and $A$. tumefaciens $\mathrm{C} 58 \mathrm{Cl}(\mathrm{pGV} 2201)$ as controls, the 20 mutants all formed rough tumours indistinguishable from those induced by the wild-type parent harbouring the same Ti-plasmid (data not shown). This result is in agreement with those of Hawes et al. (1988), that these types of mutations have no effect on tumorigenicity when large inocula are introduced directly into a wound site. However, we have not tested our mutants for their ability to induce tumours when introduced into the soil surrounding wound sites (Hawes \& Smith, 1989).

As a test of the rhizosphere competence of the mutants, two-week-old potato seedlings, with $2-3 \mathrm{~cm}$ roots, were dipped into overnight cultures of two mutants (mot- 1 and $s s w-22)$ and the wild-type parent, and grown for a further two weeks in conditions of upward capillary watering (see Methods). The numbers of bacteria colonizing defined sections of the roots were determined (Table 2). The wild-type parent and $s s w-22$ appeared to be able to colonize all sections of the root analysed. However, mot-1, while appearing in similar numbers in the upper parts of the root, seemed to be incapable of colonizing the newly-grown lower reaches, against the flow of water. This is good evidence in favour of motility as a determinant of rhizosphere competence in $\boldsymbol{A}$. tumefaciens.

\section{Genotypes of the behavioural mutants}

To assess whether the 20 behavioural mutants were independent in origin, and resulted from a single $\operatorname{Tn} 5$ insertion, chromosomal DNA was purified from each, and digested with EcoRI (see Methods). The resulting fragments were separated on a $0.8 \%$ agarose gel, blotted to nitrocellulose and probed with a radioactively labelled internal $B g / I I$ fragment of $\mathrm{Tn} 5$. The results for nine of the mutants are shown in Fig. 5. In each of the mutants analysed, there was a single hybridizing EcoRI fragment, ranging from 6.7 to $15 \mathrm{~kb}$. This is to be expected, as Tn5 lacks EcoRI sites, so the bands picked out by this analysis represent a genomic $E c o$ RI fragment with a $T n 5$ insert. In most of the cases, the Tn5-containing fragments were of different sizes, but in mutants mot-4, mot-9 and fla-10 (tracks 3, 8 and 9) they were of the same size. Subsequent

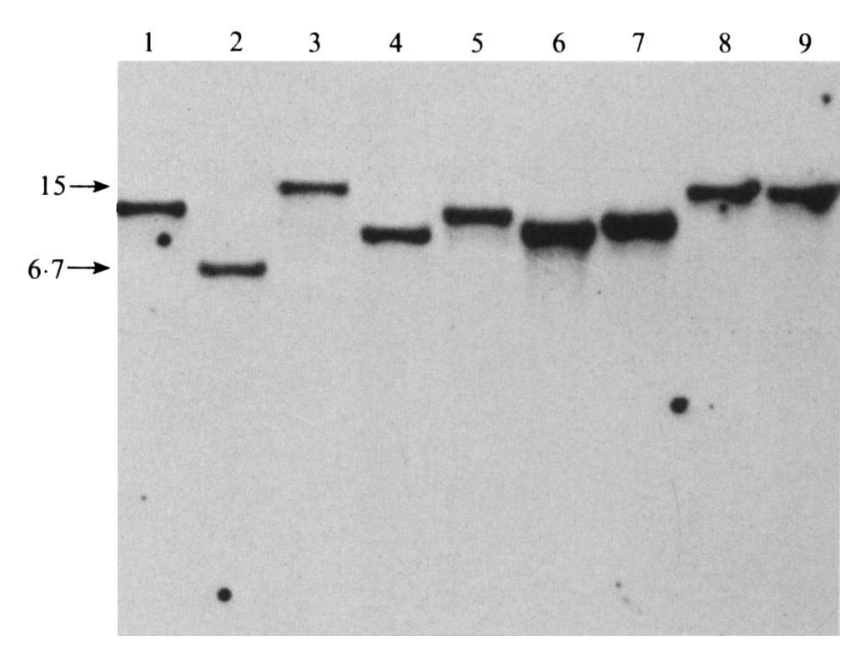

Fig. 5. Hybridization of $\operatorname{Tn} 5$ to chromosomal DNA from A.tumefaciens mutants. Chromosomal DNA from mutants 2-10 was digested with EcoRI, separated on a $0.8 \%$ agarose gel, transferred to nitrocellulose, and probed with a ${ }^{32} \mathrm{P}$-labelled $1 \cdot 1 \mathrm{~kb}$ internal $B g / \mathrm{II} \mathrm{Tn} 5$ fragment. Tracks: 1 , che- $2 ; 2$, fla-3, 3, mot $-4 ; 4$, mot $-5 ; 5$, mot $-6 ; 6$, fla $-7 ; 7$, fla- $8 ; 8$, mot-9; $9, f a-10$. Arrows indicate the sizes of the largest $(15 \mathrm{~kb})$ and smallest $(6.7 \mathrm{~kb})$ fragments containing $\mathrm{Tn} 5$.

Table 2. Root colonization assay

Values represent the mean of 10 replicates of kanamycin and rifampicin doubly resistant (mot-l and $s s w-22$ ) and rifampicin resistant $(\mathrm{C} 58 \mathrm{Cl})$ bacteria recovered from root sections.

\begin{tabular}{lccr}
\hline \hline & \multicolumn{3}{c}{ No. of bacteria } \\
\cline { 2 - 4 } & & Distance along root (cm): \\
Strain & $0-1$ & $3-4$ & $6-7$ \\
\hline C58Cl & 1200 & 1080 & 511 \\
ssw-22 & 900 & 892 & 713 \\
mot-1 & 1400 & 909 & 19 \\
\hline \hline
\end{tabular}

analysis has demonstrated that these three mutants are due to three separate and distinct $\operatorname{Tn} 5$ insertions into the same $9.3 \mathrm{~kb} E c o$ RI fragment (see below), suggesting that the mutated genes are clustered on the $A$. tumefaciens genome. Similar results, with some common and some distinct fragments carrying Tn5, were observed for the remaining mutants (data not shown). This analysis has helped to demonstrate that all of the mutants are due to separate, single $\operatorname{Tn} 5$ insertion events.

\section{Isolation of Tn5-insertion sites and behavioural gene cosmids}

The Tn 5 insertion site plus flanking sequences from each $A$. tumefaciens behavioural mutant (except ssw-20-22) was cloned into pUC18/19 (Table 3), making use of the 
fact that $\operatorname{Tn} 5$ has no EcoRI sites (Jorgensen et al., 1979). Once characterized, the mutant flanking sequences (i.e. those sequences flanking $\mathrm{Tn} 5$ ) were excised by cleavage with $E c o$ RI and $H p a I$, the latter enzyme having two sites in Tn5, 185 bp from each end (Auerswald et al., 1981; Jorgensen et al., 1979). These flanking sequences were used as hybridization probes, to identify their corresponding gene in a cosmid library of wild-type $\boldsymbol{A}$. tumefaciens DNA in pLAFR3 (Staskawicz et al., 1987) (see Table 3 and below).

\section{A. tumefaciens behavioural genes map to the chromosome}

The behavioural mutants were created in a strain of $A$. tumefaciens $\mathrm{C} 58 \mathrm{Cl}$ cured of its Ti-plasmid (van Larebeke et al., 1974). However, it still possesses the cryptic plasmid pAtC58, and it was possible that the mutations would map to this plasmid. To test this hypothesis, flanking sequences from mot-l (pDUB1801) and mot-6 (pDUB1806) were hybridized against digests of total DNA from $A$. tumefaciens $\mathrm{C} 58 \mathrm{Cl}$ and $A$. tumefaciens GM19023, which lacks the cryptic plasmid pAtC58 (Rosenberg \& Huguet, 1984). As shown in Fig. 6, both probes hybridized to identical single fragments in the DNA, regardless of the presence of the cryptic plasmid. This is good evidence in favour of the Tn 5 insertions in these mutants being in chromosomal genes.

Further evidence in support of this contention was provided by pulsed-field gel electrophoresis. Total DNA from four mutants, che-2, fla-3, mot-4 and mot-6, was digested with DraI, separated on a $1.5 \%$ agarose gel using a CHEF-DRII orthogonal-field electrophoresis system (see Methods) and then probed with Tn5. As shown in Fig. 7, $\mathrm{Tn} 5$ hybridized to a $40-45 \mathrm{~kb}$ fragment in each mutant DNA. While it is possible that there is more than one fragment of that size in this region of the gel, mapping of the $A$. tumefaciens genome by this method suggests that this is not so. The mutated loci analysed in this experiment map to two separate cosmids (Table 3 and below) carrying a total of 12 loci. Thus, it is most likely that the bulk of the Tn 5 insertions into behavioural genes map to the $A$. tumefaciens chromosome.

\section{Similarity of Agrobacterium and Rhizobium behavioural genes}

Rhizobium and Agrobacterium share a number of common features, with respect to motility (Loake et al., 1988) and their interactions with plants (Shaw et al., 1988b). It was therefore of interest to determine whether their behavioural genes share any similarity. Similarly, it was important to ascertain whether there was any similarity

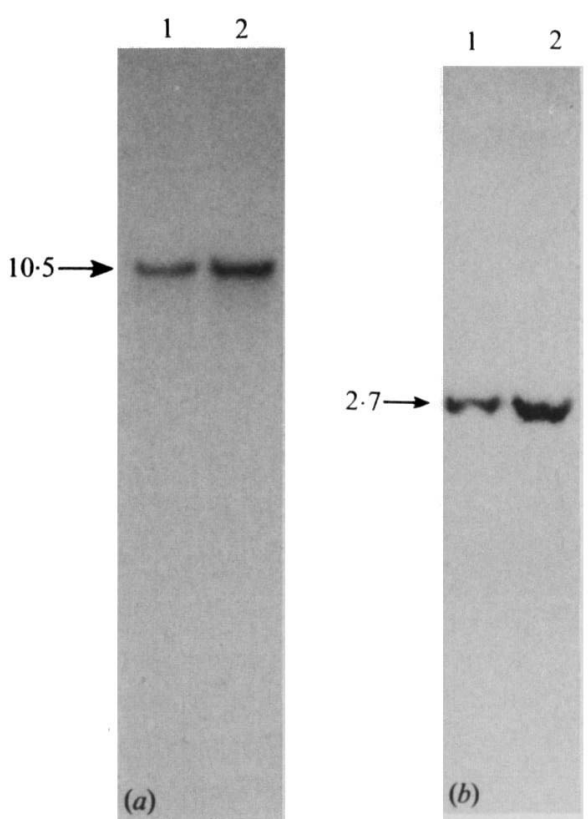

Fig. 6. Hybridization of mot-l (a) and mot-6 (b) flanking sequences to $H$ HindII $(a)$ and EcoRI $(b)$ digested total DNA from $A$. tumefaciens C58C1 (tracks 1) and A. tumefaciens GM19023, which lacks the large cryptic plasmid (tracks 2). Arrows indicate sizes of hybridizing fragments in $\mathrm{kb}$.

Table 3. Properties of behavioural gene cosmids

\begin{tabular}{|c|c|c|c|}
\hline Mutant & $\begin{array}{l}\text { Plasmid } \\
\text { containing } \\
\text { Tn5-flanking } \\
\text { sequences }\end{array}$ & $\begin{array}{l}\text { Cosmid } \\
\text { hybridizing to } \\
\text { flanking } \\
\text { sequences }\end{array}$ & $\begin{array}{c}\text { Cosmid } \\
\text { complementing } \\
\text { mutant }\end{array}$ \\
\hline mot -1 & pDUB1801 & pDUB 1900 & pDUB 1900 \\
\hline che-2 & pDUB1802 & pDUB 1905 & pDUB1905 \\
\hline fla-3 & pDUB1803 & pDUB 1900 & pDUB 1900 \\
\hline mot -4 & pDUB1804 & pDUB 1900 & pDUB 1900 \\
\hline mot -5 & pDUB1805 & - & - \\
\hline$m o t-6$ & pDUB 1806 & pDUB1905 & pDUB 1905 \\
\hline fla-7 & pDUB1807 & pDUB1901/2/3 & ND \\
\hline fla -8 & pDUB1808 & pDUB 1905 & pDUB1905 \\
\hline mot -9 & pDUB 1809 & pDUB 1900 & pDUB 1900 \\
\hline fla -10 & pDUB 1810 & pDUB 1900 & \\
\hline fla-11 & pDUB1811 & pDUB 1900 & pDUB 1900 \\
\hline$m o t-12$ & pDUB1812 & pDUB 1900 & \\
\hline$m o t-14$ & pDUB 1814 & pDUB 1900 & pDUB 1900 \\
\hline$f a-15$ & pDUB1815 & pDUB 1900 & pDUB1900 \\
\hline$t p c-17$ & pDUB1817 & pDUB 1904 & ND \\
\hline$s s w-18$ & pDUB1818 & - & - \\
\hline fla- 19 & pDUB1819 & pDUB1906 & ND \\
\hline
\end{tabular}

ND, Not determined.

between the behavioural genes we have isolated and genes from other Gram-negative bacteria. A number of hybridization experiments were performed in which several different flanking sequences from $A$. tumefaciens 


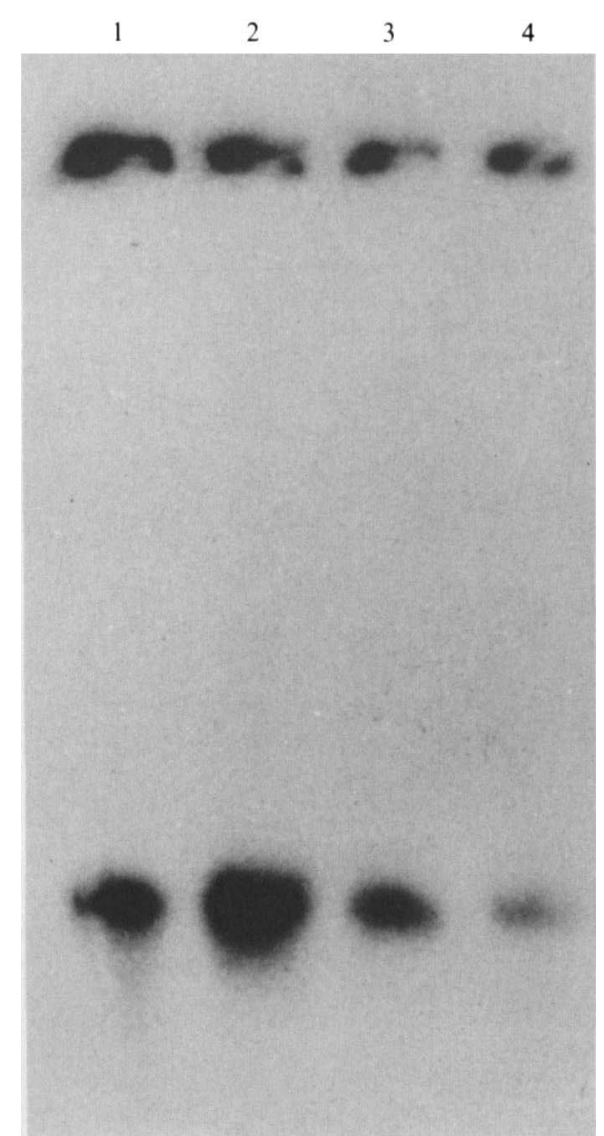

Fig. 7. Hybridization of Tn5 to total DNA from A. tumefaciens mutants, digested with Dral and separated by pulsed-field gel electrophoresis. Tracks: 1 , che-2; 2, fla-3; 3, mot-4; 4, mot-6. Hybridizing bands near the top are residual DNA left in the slots. The bands further down the gel are approximately $40-45 \mathrm{~kb}$ in size.

behavioural mutants were used as probes against 'zoo' blots (Figs 8-10). These Southern blots were prepared by transferring to nitrocellulose or nylon, digested, electrophoresed DNA from E. coli, A. tumefaciens, three strains of Rhizobium and two of Pseudomonas, and two cosmids, pRZ2 and pRZ4, which represent contiguous regions of the $R$. meliloti genome encoding behavioural genes (Ziegler et al., 1986).

None of the behavioural genes isolated in this work showed any hybridization with $E$. coli DNA (see for example Fig. 8, track 1, and Fig. 9, track 3) or with $P$. reactans and $P$. talassii DNA (Fig. 8, tracks 8 and 9, Fig. 9 , tracks 10 and 11). However, varying degrees of similarity were evident with Rhizobium DNA. Thus flanking sequences from $A$. tumefaciens fla-7 (pDUB1807) and $f l a-11$ (pDUB1811) showed very weak hybridization with $R$. meliloti DNA (Fig. 8, tracks 4 and 5, Fig. 9, tracks 6 and 7) but not with $R$. leguminosarum (Fig. 8, tracks 6 and 7, Fig. 9, tracks 8 and 9). In the case of $f a-11$, the hybridizing sequences have been localized to a $2 \mathrm{~kb} E c o$ RI fragment of the cosmid pRZ2 (Fig. 9, track 1). For the $A$. tumefaciens behavioural genes mot-1 (pDUB1801) and che-2 (pDUB1802) the similarity to $R$. meliloti genes was much more pronounced (Fig. 10). The hybridizing bands in this case mapped to two adjacent EcoRI fragments of pRZ4. The region to which mot-1 hybridized (the $11.5 \mathrm{~kb} E c o \mathrm{RI}$ pRZ4 fragment) carries several $R$. meliloti che genes, a mot gene (Ziegler et al., 1986), and the two flagellin genes (Pleier \& Schmitt, 1989) but no functions have been ascribed to the $3.5 \mathrm{~kb}$ pRZ4 EcoRI fragment to which che-2 hybridized (Ziegler et al., 1986). This suggests the similarity of some of the $A$. tumefaciens behavioural genes and their counterparts in $R$. meliloti, indicating that the flanking sequences we have isolated are indeed from behavioural genes of $A$. tumefaciens.

\section{Analysis of $A$. tumefaciens cosmids}

Initially the cosmid library containing wild-type $A$. tumefaciens DNA was screened with radioactively labelled mutant flanking sequences from pDUB1801 (mot-1), pDUB1806 (mot-6), pDUB1807 (fla-7), pDUB1817 (tpc-17) and pDUB1819 (fa-19). This resulted in the isolation of seven cosmids (Table 3 ): pDUB1900 (mot-1), pDUB1901/2/3 (fla-7), pDUB1904 (tpc-17), pDUB1905 (mot-6) and pDUB1906 (fla-19). pDUB1901/2/3 share a common $14 \mathrm{~kb}$ BamHI fragment, and represent overlapping segments of the same chromosomal region. The other four cosmids do not share any common DNA fragments, and we thus conclude that they all contain separate, non-overlapping regions of the A. tumefaciens genome. As yet, no other flanking sequences have been shown to hybridize to cosmids pDUB1901-4 and pDUB1906. At present these cosmids thus have only one behavioural gene mapped to them. However, cosmids pDUB1900 and pDUB1905 have subsequently been shown to carry multiple behavioural genes.

The existence of several behavioural genes on cosmids pDUB 1900 and pDUB 1905 has been determined by two different methods (Table 3): complementation of mutant phenotypes; and hybridization of flanking sequences from other mutants to them. Using pRK2013 to mobilize cosmids from $E$. coli into $A$. tumefaciens behavioural mutants, pDUB1905 has been shown to complement mutants che-2 (Fig. 11a) mot-6 (Fig. 11b) and fla-8, data confirmed by the hybridization of the corresponding mutant flanking sequences to this cosmid (Table 3).

Restriction mapping using the enzymes HindIII, $B a m \mathrm{HI}, E c o \mathrm{RI}$ and HpaI of the cosmid pDUB1900 allowed the construction of the map shown in Fig. 12. As 


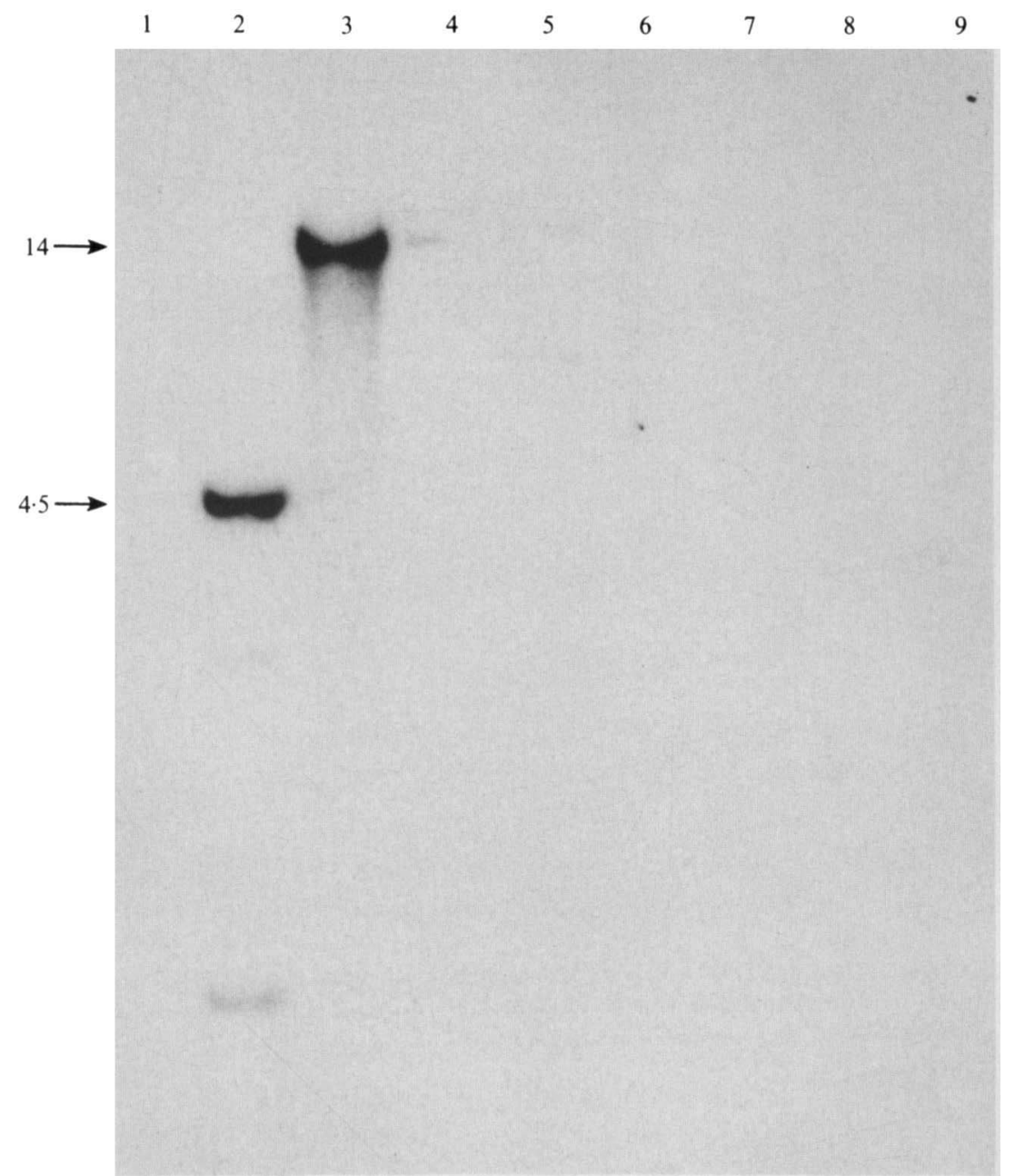

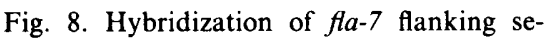
quences to BamHI (tracks 3 and 5) or EcoRI (all other tracks) digested chromosomal DNA from E. coli (1), A. tumefaciens (2 and 3), R. meliloti (4 and 5), $R$. leguminosarum biovar viciae (6), $R$. leguminosarum biovar phaseoli (7), $P$. reactans (8), and $P$. talassii (9). Arrows indicate sizes of hybridizing fragments in $\mathrm{kb}$. this cosmid complements the behavioural mutants mot-1, 4, 9 and 14, and $f l a-3,11$ and 15 (Table 3), flanking sequences from these and other mutants were used as hybridization probes against Southern blots of digested pDUB1900 DNA. This confirmed that flanking sequences from mot-1,4, 9, 12 and 14 , and $f l a-3,10,11$ and 15 , hybridize to pDUB1900 and served to position the hybridizing sequences on the pDUB1900 map (Fig. 12). The existence of $H p a I$ sites in EcoRI fragments A and B of pDUB 1900 meant that these sites were also present in the flanking sequences of mutants mot-4, 9, 12 and 14, and $f l a-10$ and 15 . This facilitated the accurate positioning of the Tn5 insertions in these mutants. Mapping of the sequences hybridizing to flanking sequences from mutant $f l a-3$ led to the conclusion that in this mutant there is a $4 \mathrm{~kb}$ deletion adjacent to the $\operatorname{Tn} 5$ insertion site.

Probing of EcoRI-digested total DNA from mutants mot -4 , mot -9 and $f l a-10$ with $\operatorname{Tn} 5$ revealed that all three mutants had similar-sized hybridizing fragments (Fig. 5). The $\operatorname{Tn} 5$ insertions in these three mutants map close together in EcoRI fragment B of pDUB1900. The EcoRI site that defines the left end of fragment $B$ is in fact from the multiple cloning site of pLAFR3. However, analysis of plasmids pDUB1804 (mot-4), pDUB1809 (mot-9) and pDUB1810 ( $f$ la-10), which all contain fragments extending beyond the boundaries of pDUB1900, has confirmed that these $\operatorname{Tn} 5$ insertions are all in a common $9.3 \mathrm{~kb}$ EcoRI fragment of $A$. tumefaciens chromosomal DNA. Mapping confirms that these are three distinct insertions, with $1.2 \mathrm{~kb}$ separating the mot -9 and 4 insertions, and 300 bp between mot -4 and $f l a-10$. Similarly, the Tn5 insertions in mot-12 and 14 are both in EcoRI fragment A and appear to be spaced approximately $50 \mathrm{bp}$ apart. Thus, pDUB1900 carries a number of genes concerned 


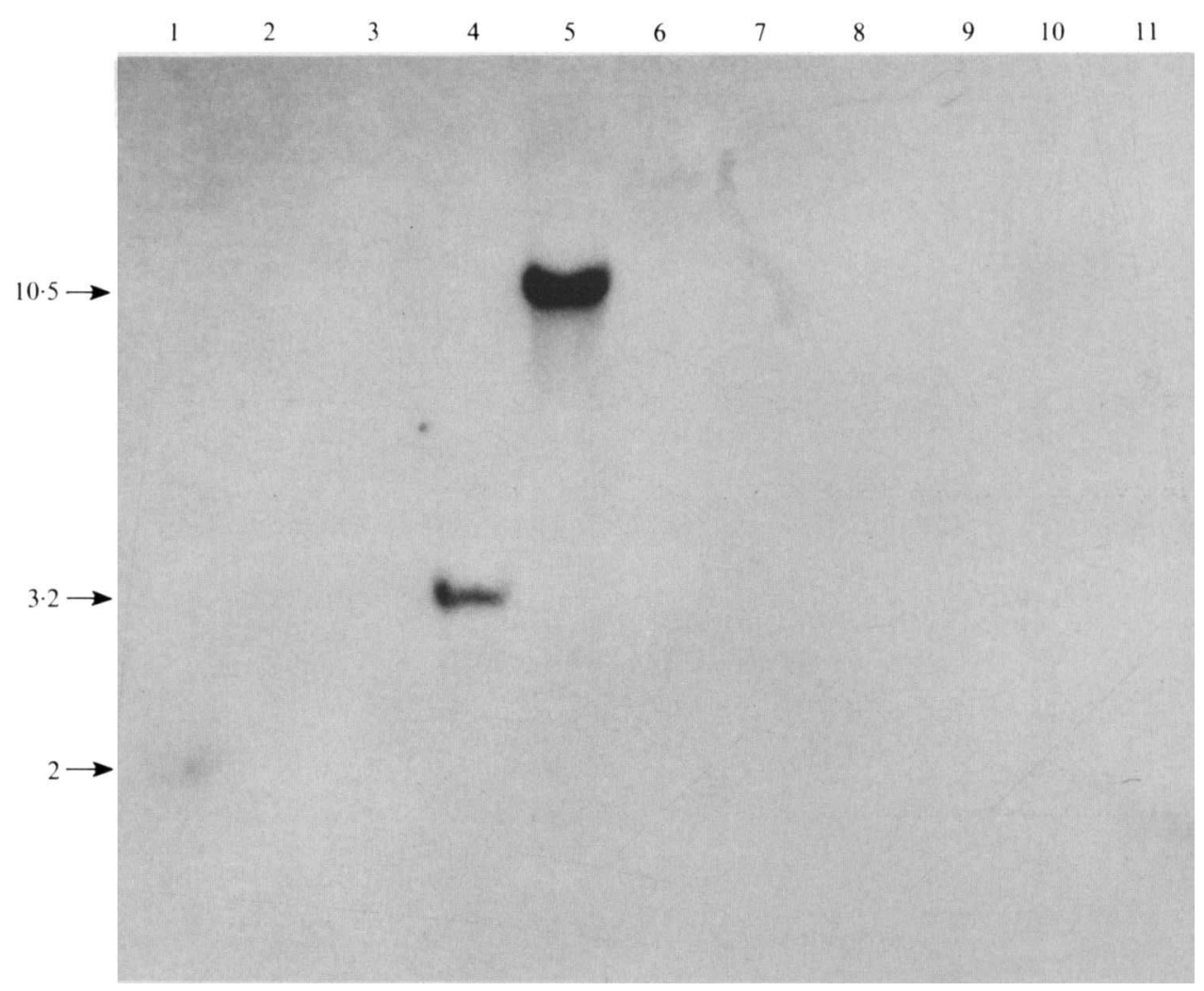

Fig. 9. Hybridization of $f a-11$ flanking sequences to HindIII (tracks 5 and 7) or EcoRI (all other tracks) digested cosmids pRZ2 (track 1) and pRZ4 (track 2), both of which carry behavioural genes from R. meliloti, and chromosomal DNA from E. coli (3), A. tumefaciens (4 and 5), $R$. meliloti (6 and 7), $R$. leguminosarum biovar viciae (8), $R$. leguminosarum biovar phaseoli (9), P. talassii (10) and $P$. reactans (11). Arrows indicate sizes of hybridizing fragments in $\mathrm{kb}$.

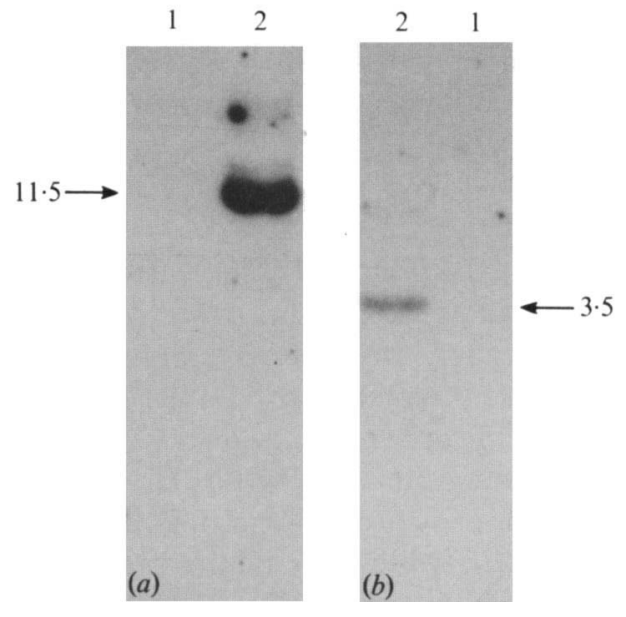

Fig. 10. Hybridization of mot-l $(a)$ and che-2 $(b)$ flanking sequences to EcoRI-digested cosmids pRZ2 (tracks 1) and pRZ4 (tracks 2) carrying behavioural genes from $R$. meliloti. Arrows indicate sizes of hybridizing fragments in $\mathrm{kb}$.

with motility and chemotaxis in $A$. tumefaciens, confirming that as in $R$. meliloti, these genes are clustered in the chromosome.

\section{Discussion}

This paper describes the isolation and characterization of 20 behavioural mutants of $A$. tumefaciens, and the initial characterization of the corresponding genes. Martha Hawes and coworkers have described a set of Tn5-induced mutants of $A$. tumefaciens (Hawes \& Smith, 1989; Hawes et al., 1988) and together with the present work these have served to demonstrate the role of chemotaxis and motility in rhizosphere competence and virulence of this organism.

Analysis of the behavioural mutants and their wildtype parent has highlighted the unusual flagellation pattern. The presence of a polar tuft, at only one pole, and lateral flagella suggests that there is some polarity to the cell. Mutant mot-12, which lacks the polar tuft, points to the possibility that in some way the polar and lateral flagella are non-equivalent.

The paucity of non-chemotactic mutants isolated by our methods could be due to the rarity of their genes in the genome, compared to motility genes. However, it is worth pointing out that our method, using a complex attractant mixture during mutant screening, would only 

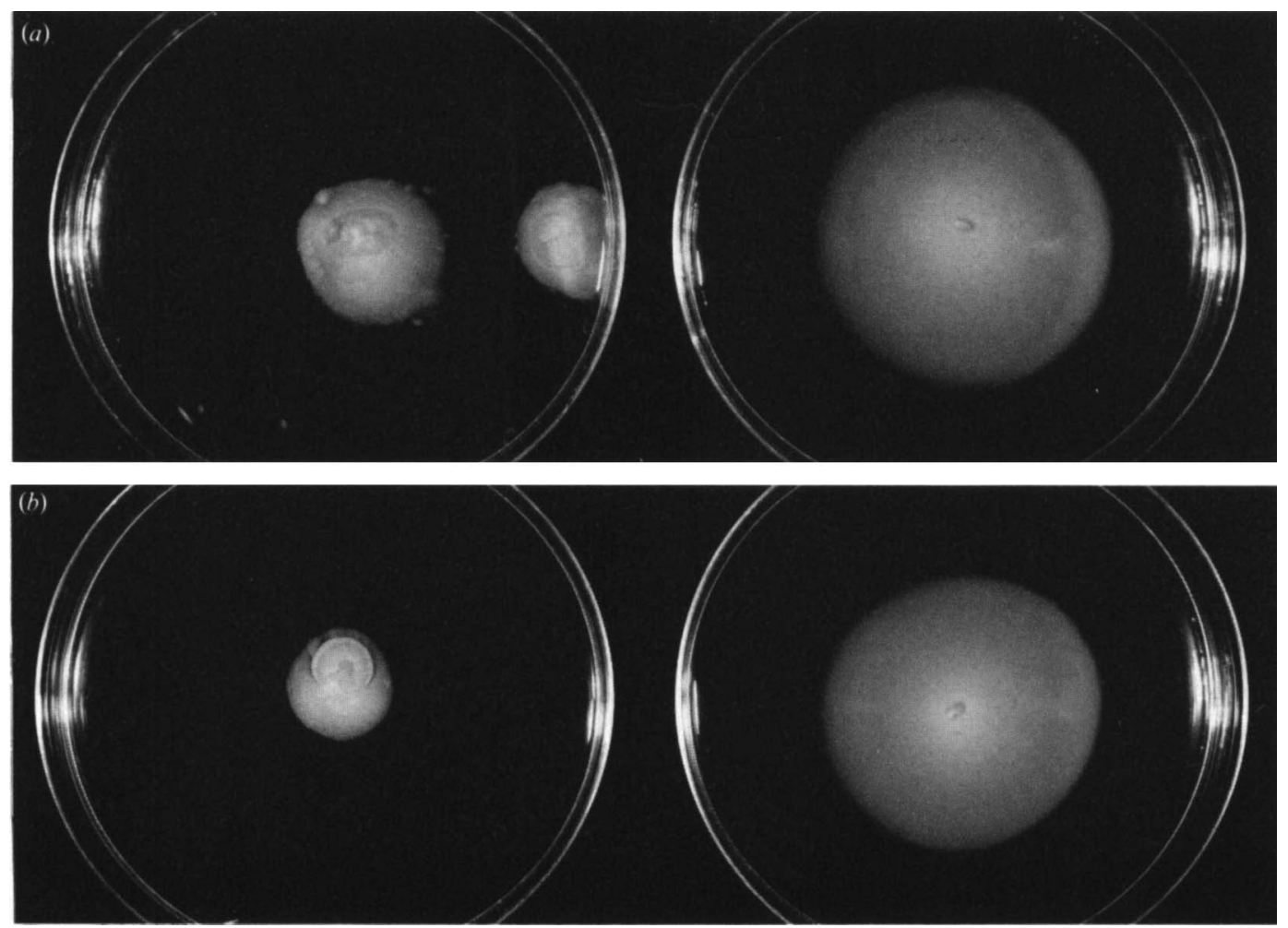

Fig. 11. Complementation of mutants che-2 and mot-6 by cosmid pDUB1905. (a) Swarm plates of $A$. tumefaciens $\mathrm{C} 58 \mathrm{C} 1$ che-2 (left) and A. tumefaciens $\mathrm{C} 58 \mathrm{Cl}$ che-2(pDUB1905) (right). (b) Swarm plates of $A$. tumefaciens $\mathrm{C} 58 \mathrm{Cl}$ mot-6 (left) and $A$. tumefaciens $\mathrm{C} 58 \mathrm{Cl}$ mot-6(pDUB1905) (right).
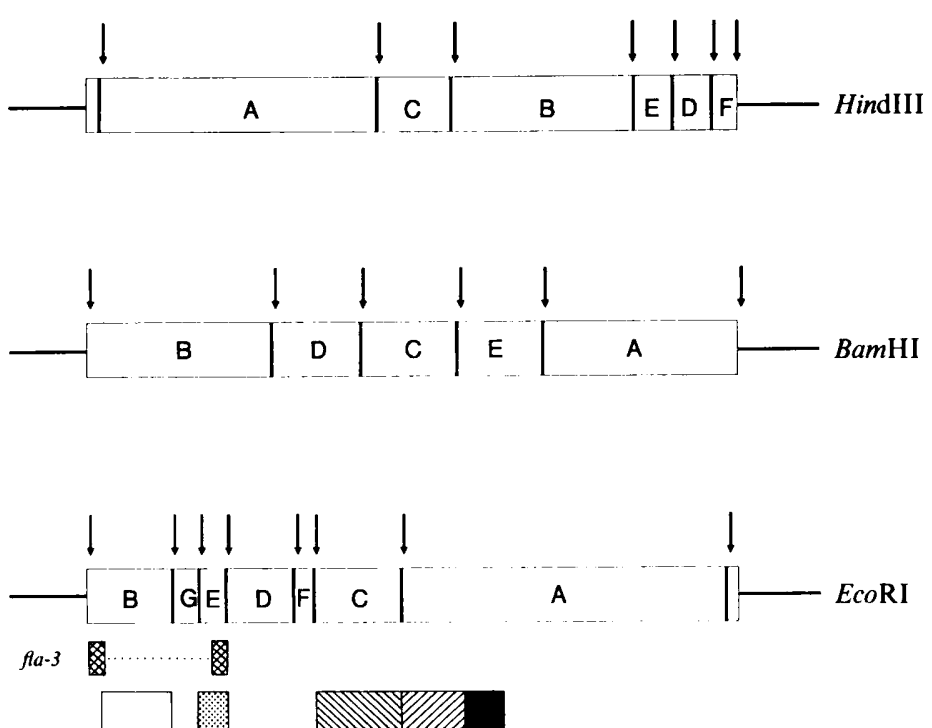

mot-4 mot-1

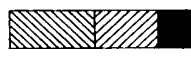

mot-9

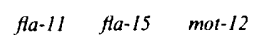

fla-10

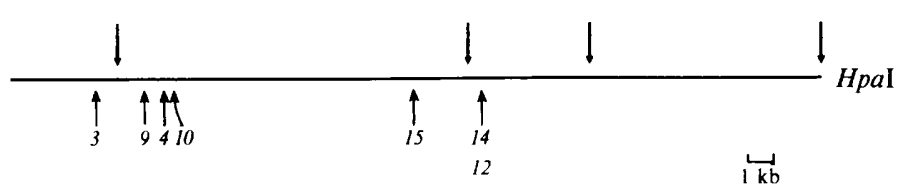

Fig. 12. Restriction map of the $A$. tumefaciens chromosomal DNA insert in cosmid clone pDUB1900. The top three panels show the restriction maps for HindIII, Bam HI and EcoRI. The EcoRI site to the left, and the HindIII site to the right of the insert, derive from the multiple cloning site of pLAFR3. Below that are shown the approximate positions of sequences hybridizing to the various mutants (boxes) and the extent of the deletion in $f a-3$ (dotted line). At the bottom are shown the cleavage sites for $\mathrm{HpaI}$, and the mapped locations of the Tn 5 insertions in mutants $f l a-3,10$ and 15 , and mot-4, 9, 12 and 14 . The Tn 5 insertions in mot-12 and 14 are within $50 \mathrm{bp}$ of each other, below the resolution of the figure. 
have led to the isolation of generally non-chemotactic mutants, i.e. those affected in the cytoplasmic signalling pathway. Moreover, some of the non-motile, but flagellated mutants, which we have designated mot, may in fact have paralysed flagella due to a defect in the signalling pathway.

Hybridization of mot- 1 and 6 flanking sequences to DNA from an $A$. tumefaciens strain cured of both $\mathrm{Ti}$ - and cryptic plasmids confirmed that these particular $\operatorname{Tn} 5$ insertions were chromosomal. The pulsed-field gel data suggest that mot-6 is linked to che-2, fla-3 and mot-4. As the flanking sequences from these mutants map to two separate cosmids which together encode mot-1, 4, 6, 9, 12 and $14, f a-3,8,10,11$ and 15 , and che-2, this suggests that the bulk of the $\operatorname{Tn} 5$ insertions in the behavioural mutants are into linked sections of the chromosome.

The isolation of cosmids encoding the behavioural genes demonstrates that these functions are clustered in the $A$. tumefaciens genome, as they are in $R$. meliloti (Ziegler et al., 1986). This will facilitate further characterization, and DNA sequencing. However, the estimates of about 60 genes involved in chemotaxis and motility in E. coli (Macnab, 1987a,b) suggest that we have not identified all of the genes in $A$. tumefaciens. Saturation mutagenesis of the isolated cosmids followed by homogenotization should aid in identifying linked genes, not yet mutagenised.

The authors would like to thank their colleagues in the Playgroup for making science fun, and Dr M. Daniels (Norwich) for pJB4JI and pLAFR3, Dr J. Denarie (Toulouse) for $A$. tumefaciens GM19023, Dr K. Bergman (Boston) for $R$. meliloti and the cosmids pRZ2 and pRZ4, Professor A. Johnston (Norwich) for $R$. leguminosarum biovars viciae and phaseoli, Dr A. M. Ashby (Cambridge) for Pseudomonas talassii and $P$. reactans, and Katherine Philips for preliminary mapping of pDUB1809, '10, '14 and '15. G. J. L., A.P. B. and W.D. were supported by studentships from the Science and Engineering Research Council.

\section{References}

ADLER, J. (1973). A method for measuring chemotaxis and use of the method to determine optimum conditions for chemotaxis by Escherichia coli. Journal of General Microbiology 74, 77-91.

Aguilar, J. M. M., Ashby, A. M., Richards, A. J. M., Loake, G. J., Watson, M. D. \& SHaw, C. H. (1988). Chemotaxis of Rhizobium leguminosarum biovar phaseoli towards flavonoid inducers of the symbiotic nodulation genes. Journal of General Microbiology 134, $2741-2746$.

Ames, P. \& Bergman, K. (1981). Competitive advantage provided by bacterial motility in the formation of nodules by Rhizobium meliloti. Journal of Bacteriology 148, 728-729.

Ashby, A. M., Watson, M. D. \& Shaw, C. H. (1987). A Ti-plasmid determined function is responsible for chemotaxis of Agrobacterium tumefaciens towards the plant wound product acetosyringone. FEMS Microbiology Letters 41, 189-192.

Ashby, A. M., Watson, M. D., Loake, G. J. \& Shaw, C. H. (1988). Tiplasmid specified chemotaxis of Agrobacterium tumefaciens $\mathrm{C} 58 \mathrm{Cl}$ toward vir-inducing phenolic compounds and soluble factors from monocotyledonous and dicotyledonous plants. Journal of Bacteriology 170, 4181-4187.
Auerswald, E. A., Ludwig, G. \& Schaller, H. (1981). Structural analysis of Tn5. Cold Spring Harbor Symposia on Quantitative Biology 45, 107-113.

Bourret, R. B., Hess, J. F., Borkovich, K. A., Pakula, A. \& Simon, M. I. (1989). Protein phosphorylation in chemotaxis and two component regulatory systems of bacteria. Journal of Biological Chemistry 264, 7085-7088.

Dhaese, P., De Greve, H., Decraemer, H., Schell, J. \& vaN MONTAGU, M. (1979). Rapid mapping of transposon insertion and deletion mutants in the large Ti-plasmids of Agrobacterium tumefaciens. Nucleic Acids Research 7, 1837-1849.

Flanagan, J. L., Ventra, L. \& Weiss, A. S. (1989). Rapid method for preparation and cleavage of bacterial DNA for pulsed-field gel electrophoresis. Nucleic Acids Research 17, 814.

HAWES, M. C. \& SMITH, L. Y. (1989). Requirement for chemotaxis in pathogenicity of Agrobacterium tumefaciens on roots of soil grown pea plants. Journal of Bacteriology 171, 5668-5671.

HaWes, M. C., Smith, L. Y. \& HowarTh, A. J. (1988). Agrobacterium tumefaciens mutants deficient in chemotaxis to root exudates. Molecular Plant-Microbe Interactions 1, 182-186.

HowARD, E. \& CitovsKy, V. (1990). The emerging structure of the Agrobacterium T-DNA transfer complex. BioEssays 12, 103-108.

Jorgensen, R. A., Rothstein, S. J. \& Reznikoff, W. S. (1979). A restriction enzyme cleavage map of $\mathrm{Tn} 5$ and location of a region encoding neomycin resistance. Molecular and General Genetics 177, 65-72.

van LARebeke, N., ENGler, G., Holsters, M., van Den ElSacker, S., ZAENEN, I., SCHILPEROORT, R. A. \& SChell, J. (1974). Large plasmid in Agrobacterium tumefaciens essential for crown gall inducing ability. Nature, London 252, 169-170.

Leemans, J., Shaw, C. H., Deblaere, R., De Greve, H., HernalSTtens, J.-P., VAN MontaGU, M. \& Schell, J. (1981). Site-specific mutagenesis of Agrobacterium Ti-plasmids and transfer of genes to plant cells. Journal of Molecular and Applied Genetics 1, 149-164.

LOAKe, G. J., AshbY, A. M. \& SHAW, C. H. (1988). Attraction of Agrobacterium tumefaciens $\mathrm{C} 58 \mathrm{C} 1$ towards sugars involves a highly sensitive chemotaxis system. Journal of General Microbiology 134, 1427-1432.

MACNAB, R. M. (1987a). Flagella. In Escherichia coli and Salmonella typhimurium: Cellular and Molecular Biology, pp. 70-83. Edited by F. C. Neidhart and others. Washington, DC: American Society for Microbiology.

MACNAB, R. M. (1987b). Motility and chemotaxis. In Escherichia coli and Salmonella typhimurium: Cellular and Molecular Biology, pp. 732759. Edited by F. C. Neidhardt and others. Washington, DC: American Society for Microbiology.

Maniatis, T., FritsCh, E. F. \& SAMBrooK, J. (1982). Molecular Cloning - a Laboratory Manual. Cold Spring Harbor, NY: Cold Spring Harbor Laboratory.

Miller, J. H. (1972). Experiments in Molecular Genetics. Cold Spring Harbor, NY: Cold Spring Harbor Laboratory.

Pleier, E. \& Schmidt, R. (1989). Identification and sequence analysis of two related flagellin genes in Rhizobium meliloti. Journal of Bacteriology 171, 1467-1475.

RosenberG, C. \& Huguet, T. (1984). The pAtC58 plasmid of Agrobacterium tumefaciens is not essential for tumour induction. Molecular and General Genetics 196, 533-536.

Shaw, C. H., Ashby, A. M., Brown, A. P., Royal, C., Loake, G. J. \& SHAw, C. H. (1988a). vir $A$ and $G$ are the Ti-plasmid functions required for chemotaxis of Agrobacterium tumefaciens toward acetosyringone. Molecular Microbiology 2, 413-418.

Shaw, C. H., Ashby, A. M., Loake, G. J. \& Watson, M. D. (1988b). One small step: the missing link in crown gall. Oxford Surveys of Plant Molecular and Cell Biology 5, 177-183.

Staskawicz, B., Dahlbeck, D., Keen, N. \& Napoli, C. (1987). Molecular characterisation of cloned avirulence genes from race 0 and race 1 of Pseudomonas syringae pv. glycinae. Journal of Bacteriology 169, 5789-5794.

STEWART, R. C. \& DAHLQUiST, F. W. (1987). Molecular components of bacterial chemotaxis. Chemical Reviews 87, 997-1025.

Stock, J. B., Stock, A. M. \& Mottonen, J. M. (1990). Signal transduction in bacteria. Nature, London 344, 395-400. 
TAYlor, B. L. \& Lengeler, J. W. (1990). Transductive coupling by methylated transducing proteins and permeases of the phosphotransferase system in bacterial chemotaxis. In Membrane Transport and Information Storage, pp. 69-90. New York: Alan R. Liss.

De Weger, L. A., van der Vlugt, C. I. M., WiJfjes, A. H. M., BAKKeR, P. A. H. M., SChippers, B. \& LugtenberG, B. J. J. (1987)

Flagella of a plant-growth-stimulating Pseudomonas fuorescens strain are required for colonisation of potato roots. Journal of Bacteriology 169, 2769-2773.

ZAMBR YSKI, P., TeMPE, J \& SCHELl, J. (1989). Transfer and function of $\mathrm{Ti}$ and $\mathrm{Ri}$ plasmids in plants. Cell 56, 193-201.

Ziegler, R. J., Pierce, C. \& Bergman, K. (1986). Mapping and cloning of a fla-che region of the Rhizobium chromosome. Journal of Bacteriology 168, 785-790. 